THURSDAY, APRIL 30, I89I.

\section{THE SCIENCE MUSEUM AND GALLERY OF BRITISH ART AT SOUTH KENSINGTON.}

THE memorial which we print below, and which is still in course of signature, shows with no uncertain sound what is the general opinion of men of science with regard to the suggested allocation of the plot of ground opposite the Royal College of Science for an Art Gallery.

The memorialists, of course, are as appreciative as others of Mr. Tate's munificent offer, nor do they in the least object to the erection of art galleries; their only point is that the plot of ground in question finds its natural use in the additional buildings for the College, for which, indeed, it was understood plans have been for some time in course of preparation.

The reason for this is not far to seek. Not only is it convenient that the two halves of the College should be as near together as possible, but the professors in both use daily in their lectures the apparatus in the Science Museum; there is therefore necessarily the most intimate connection with the buildings in which the teaching is carried on, and those in which the materials for teaching are stored.

The suggested arrangement sunders them as far as possible from each other.

The treatment of the needs and claims of science by Ministers of all shades of party politics may probably account for the present dilemma. It may turn out that those who are responsible for having made the offer to Mr. Tate had not an idea that there was the slightest objection to the proposed action; and not only so, but it is quite possible, and we believe it is true, that the scientific authorities of the Science and Art Department were never consulted at all in the matter.

It is from this point of view that the Memorial, representing the opinion of Oxford, Cambridge, Edinburgh, and the other teaching centres in London, not to mention the President and Officers of the Royal and other scientific Societies, is of so great importance.

Men of science have waited patiently for nearly 20 years for the realization of the recommendation of the Duke of Devonshire's Commission that the pure and applied sciences, on which our national industries depend, should be treated like the other branches of human knowledge. Natural history, antiquities, literature, and art, find places in our Museum system. Why, then, not physical science?

During these years Committee after Committee has been appointed. They have all endorsed the recommendation to which we have referred ; but the Government cares so little for these things, that some years ago, in 1877 , they refused the offer of the ground on which the Imperial Institute is now being erected and $£_{100,000}$ for a building, from the Royal Commissioners of the $185 \mathrm{I}$ Exhibition.

Penultimately a Committee appointed by the Treasury reported that the claims of science were just and must be met. The Treasury then found $f_{100,000}$ to buy the land they might have got for nothing more than ten years ago.

And now finally, as it would appear, lest they should be tempted to carry out their own intentions of a year ago, they hand aver to an Art Gallery a large slice of the land bought for Science, and that slice the one which, in the opinion of everybody whose opinion is worth having, if thus occupied, will make the whole transaction ridiculous.

The Memorial, which is still in course of signature, runs as follows:--

Memorial to the Most Honourable the Marquis of Salisbury, K.G., F.R.S., Premier and Secretary of State for Foreign Affairs.

I. Whereas in I 890 Parliament voted $£ 100,000$ for the purchase of a site at South Kensington upon which to erect suitable buildings for the Science Museum of the Department of Science and Art and for the extension of its Science Schools; in accordance with the recommendations of the Royal Commission over which the Duke of Devonshire presided in I874, as well as of various Committees and other high scientific authorities and of a Treasury Committee appointed in 1889 ,

II. And whereas it has recently been proposed to appropriate a considerable portion of this site nearest to those institutions $\mathrm{fc}$ the erection of a new Gallery of British Art,

III. And whereas it has been decided that this Gallery shall have no connection with the Science and Art Department; a building devoted to Art, under independent administration, being thus interpolated between the two parts of a Scientific Institution under that Department,

IV. And whereas it is obviously expedient that, whatever arrangements may be made, the various portions of the Science Museum and of the Science School should be as close as possible to, and in direct contiguity with, one another-for the reason that the Instruments and Museum specimens exhibited in the one have to be used by the Professors and students in the other-and that this will not be the case if the Science Collections are housed in the East and West Picture Galleries as proposed,

We desire most respectfully to express to your Lordship our strong opinion that the development and efficiency of the Science Museum and of the Science School and Laboratories of the Department of Science and Art will be seriously jeopardized by any arrangements that may be made for erecting a Gallery of British Art upon that portion of the land which was recently purchased by Parliament; and that this site is none too large, seeing the progress that is being made in the matter of Scientific and Technical Instruction, to provide for the future requirements of the Collections and Schools controlled by the Department of Science and Art ; and that we would therefore earnestly entreat that another site should be found for the proposed Gallery of British Art.

Sir William Thomson, President of the Royal Society, Professor of Natural Philosophy, University of Glasgow.

Michael Foster, F.R.S., Secretary Royal Society, Professor of Physiology, Cambridge.

Lord RAYLEIGH, F.R.S., Secretary Royal Society, Professor of Physics, Royal Institution.

Sir Douglas Gal'Ton, K.C.B., F.R.S., General Secretary British Association.

Sir James PAGET, Bart., F.R.S., late President Royal College of Surgeons.

General STRACHEy, C.S.I., F.R.S., Chairman Meteorological Council.

RoBERT H. SCOTT, F.R.S.,.Secretary Meteorological Council.

W. Burdon Sanderson, F.R.S., Professor of Physiology, Oxford.

Sir William Turner, F.R.S., Professor of Anatomy, University of Edinburgh.

T. McKenny Hughes, F.R.S., Woodwardian Professor, Cambridge.

W. H. M. Christie, F.R.S., Astronomer-Royal, Past President Royal Astronomical Society.

Etrrick W. Creak, Commander R.N., F.R.S.

W. T. Blanford, F.R.S., Iate Director Meteorological Department, India.

JOHN RAE, F.R.S.

Francis Galton, F.R.S., President Kew Observatory.

Prof. W. H. Flower, C.B., F.R.S., Director Natural History Museum.

NO. I 122 , VOL. 43] 
P. L. Sclater, F.R.S., Secretary Zoological Society.

Sir William RoberTs, M.D., F.R.S.

Hugo Müller, F.R.S., Past President Chemical Society.

Dr. E. FrankLand, F.R.S., Past President Chemical Society.

Dr. J. H. Gilbert, F.R.S., Past President Chemical Society.

Dr. W J. Russell, F.R.S., Past President Chemical S sciety.

Prof. Raphael Meldola, F.R.S., Foreign Secretary Chemical Society.

SHELFORD BIDWELL, F.R.S.

Dr. J. H. Gladstone, F.R.S., Vice-Chairman School Board for London.

Sir Richard Quain, Bart., F.R.S., President Royal College of Physicians.

Prof. W. E. Ayrton, F.R.S., President Physical Society.

Prof. John Perry, F.R.S., Secretary Physical Society.

Prof. W. Grylls Adams, F.R.S., Past President Physical Society.

William Crookes, F.R.S., President Society of Telegraphic and Electrical Engineers.

T. G. Bonney, F.R.S., Professor of Geology, University College, London.

Sir William Bowman, Bart, F.R.S.

Lazarus Fletcher, M.A., F.R.S., Past President Mineralogical Society.

Sir HENRY E. Roscoe, F.R.S., M.P., Past President British Association.

Sir JoHN LUBBOCK, Bart., F.R.S., M.P., Chairman London County Council.

G. H. Darwin, F.R.S., Plumian Professor, Cambridge.

Sir G. G. Stokes, Bart., M.P., Past President of the Royal Society.

Sir Frederick Bramwell, F.R.S., Past President British Association.

Sir Bernhard Samuelson, Bart., F.R.S.

T. Archer Hirst, F.R.S., Past President Mathematical Society.

Bartholomew Price, F.R.S., Professor of Natural Philosophy, Oxford.

E. J. Stone, F.R.S., Radcliffe Observer, Oxford, Past President Royal Astronomical Society.

W. Odling, F.R.S.; Professor of Chemistry, Oxford, Past President Chemical Society.

R. B. Clifton, F.R.S , Professor of Experimental Philosophy, Oxford, Past President Physical Society.

G. CAREY Foster, F.R.S., Professor of Physics, University College, London, Past President of Physical Society and of Institute of Electrical Engineers.

\section{COUNTY COUNCILS AND TECHNICAL EDUCATION.}

THERE was one announcement in Mr. Goschen's Budget speech which came as welcome news to the friends of technical education. It was that the new grant out of the beer and spirit duties, which is at the disposal of County Councils with the power to use it for educational purposes, will not be diverted to other objects, but will be permanently renewed. In an announcement made in December last in reply to a question from Lord Hartington, the Chancellor of the Exchequer had held out the prospect of the permanence of the grant provided it were well used for the purpose for which it was granted. But none the less the definite language used on Thursday last is reassuring, and is likely to act as a useful stimulus to those few County Councils which have not yet definitely decided on the appropriation of the fund. It takes away the last shred of excuse from the obstructives who oppose entertaining any large scheme of educational organization on the ground that the grant should be treated as a windfall and not as income.

We have before us two small volumes recently issued by the National Association for the Promotion of Technical and Secondary Education, containing two series of NO I I 22 , VOL. 43$]$ selected reports of County Councils, and other typical schemes and proposals which have been drawn up in various districts for the utilization of the new fund These publications, issued with the view of giving the various County Councils full and timely information as to what is being done and proposed elsewhere, bear welcome testimony to the energy and ability with which, as a whole, the County Councils are grappling with the unaccustomed task which the possession of the new grant entails upon them. It is highly creditable that only two County Councils in England (London and Middlesex) have as yet failed entirely to rise to the level of their new opportunities, and have yielded to the sordid temptation to sink the whole of the first year's revenue in the rates. There is already evidence that Middlesex means next year to reconsider its hastily-adopted policy, and a scheme is already being drafted for that county. Of the case of London we shall have more to say presently.

Of the remaining English Councils, 29 have devoted the whole, and 9 part of the fund to educational purposes. In 8 more counties the special Committees appointed to consider the matter have not yet finally reported, but in nearly every case their report is likely to be in favour of the application of the money to education. In Wales, which has a separate and more comprehensive Act of its own, which it is to be hoped will shortly be extended to England, almost the whole of the fund is being divided between the purposes of technical and intermediate education. In Scotland, unfortunately, very little has as yet been done, owing largely to the cumbrous and ineffective machinery of the Technical Schools Act which is in force in that country. The amendment of that Act is urgently required in order to prevent the whole or major part of the Scotch grant from falling into the rates.

Taking the country as a whole, there cannot be a doubt of the immense stride that has been taken during the last few months in the matter of national education, and the stirring up of interest in the subject all over the country is quite as valuable as the actual assistance given out of the fund. It is indeed almost necessary to warn County Councils against the temptation to move too fast, and to adopt schemes which will at once absorb the whole grant, and create vested interests hard to deal with in the future. The whole matter is in an experimental stage, the problem of the organization of technical education by counties being completely new. In attacking such a problem blunders are certain to be made, and money is certain to be wasted at first. Fresh legislation will probably be needed before County Councils possess the requisite powers to deal comprehensively with the whole question, and it will be well for them at least to be alive to the danger of creating future difficulties by tying up the whole grant at once. Up to a few months ago there was a danger lest the grant should cease to be applicable to education if unappropriated within the financial year. All doubt, however, on this point has now been removed by Sir Henry Roscoe's Act of the present session, under which full powers are possessed by County Councils of banking and accumulating any unappropriated balance.

It is fair to say that the schemes before us recognize for the most part the danger to which we have alluded, 